\title{
The ‘Settlers And Colonists’ Affair
}

Scott HAMES

forthcoming in Alasdair Gray: Ink for Worlds, ed. Camille Manfredi

(London: Palgrave Macmillan, 2014)

Over five decades as a published writer, Alasdair Gray has enjoyed a remarkably warm press. The scathing anti-blurbs on the book jackets are, of course, fictions written for the author's own amusement. Under the sportive self-critique (and self-loathing) is an artist whose creative powers flourish when discursively against, and who is refreshingly un-defensive when challenged. In this respect Gray shares in the assertive swagger of his character Kelvin Walker, the Scottish opinionmerchant who savours rhetorical combat and the attention of a mass audience hungry for his 'divine certainties': 'people who like living in a lawful universe with a real ceiling over their head' (Gray, 1985, p.121). Gray's own appetite for moral system, and confidence in his own brisk political judgments, are central to his creativity and media appeal. (In an early television interview Lanark is somewhat patly described as a 'Scottish petit-bourgeois model of the universe'.) But the reliably quotable facet of Gray's public persona also makes him vulnerable to the fate of his outspoken character, brought low for the excess severity of his pronouncements and for embarrassing the keepers of 'The Prevailing Consensus' (Gray, 1985, p.107).

On the cusp of his televised Fall, there seems little for Kelvin to worry about:

There was no doubt at all that a cutting questioner like Kelvin Walker would be cuttingly questioned, but almost nobody who knew him doubted his ability to talk any questioner into the ground. (Gray, 1985, p.127)

But the game is rigged, his disgrace a fait accompli. Ambushed by the surprise appearance of his father, Kelvin finds himself under attack rather than interrogation. The flood of excoriation leaves no room for clever replies, and Kelvin is brutally damned even before he can be heard, reduced finally to total but un-quivering silence - even collapsed into a wordless 'egg-shape' in the television studio, a probing hand finds it 'muscularly rigid and perfectly stable' (Gray, 1985, p.133). His public destruction is complete, but Kelvin's inner assurance remains intact, almost perversely unscathed.

This scene broadly accords with my lasting impressions of the 'Settlers and Colonists' affair, in which Gray became (and was made to become) a casualty of his own incautious words, but also rendered curiously voiceless. A year later the episode has faded from public discussion, but it continues to cast a shadow over Gray's status as a 'national treasure' beloved and revered by the Scottish people - or more accurately beloved by the media, supposedly on behalf of the people. This chapter sets out the facts of the 'Settlers and Colonists' controversy from its beginnings in late 2012, followed by some impressions about what it revealed - less about Gray than the Scottish cultural and political milieu to which so much of his work is addressed. Along the way I sketch some of the circumstances key to understanding the uproar, most importantly the 2014 referendum on Scottish independence, and several tangential cultural debates.

'I wonder if Provost Lanark would care to say something quotable about what he is going to do at the Provan assembly?'

After thinking for a while Lanark said boldly, 'I will try to tell the truth'. 
'Couldn't you make it more emphatic?' said the reckless man. 'Couldn't you say,

"Come hell or high water, I will tell the world the TRUTH"'?

'Certainly not!' said Lanark crossly. 'Water has nothing to do with my visit to

Provan.'

'Come what may, the world will hear the truth,' murmured the quiet man. 'We'll quote you as saying that.' (Gray, 1981, p.465)

In the month of December 2012 the UK press published 119 stories mentioning Alasdair Gray. An average of four per day, and more than ten per day during the key week of coverage examined below. ${ }^{1}$ Comments on blogs, newspaper websites, Twitter and other social media likely numbered in the tens of thousands during the same period. (A handful of articles at the more popular newspaper websites garnered 2500 comments alone.) I mention this not to inflate the importance of this episode, viewed within the context of Gray's life and career. It was a brief but intense squall that received far more attention than its significance merited - certainly its significance to scholars of Gray's art. Nonetheless it may have lasting consequences for Gray's reputation and public image, which future researchers may struggle to decipher without a clear account of what happened, and why it happened on such a bewildering scale.

It should be emphasized from the outset that this was a controversy sparked and led by media reaction to 'Settlers and Colonists', rather than Gray's essay itself. I am stubbornly committed to debating what Gray actually wrote, rather than what others wrote about him (often in ignorance of Gray's own words) - this was a central purpose of the book project to which Gray agreed to contribute. But in order to comprehend the tumult, we need to see the essay through the prism of media reports about it. I do not, below, attempt an 'objective' exegesis of 'Settlers and Colonists' to set alongside selective reporting, cynical point-scoring and 'spin'. Gray needs no defending by me, and you can read his essay for yourself. This chapter is about the controversy rather than the essay, and the most accurate impression of the former will be gained by wading through the deluge of media commentary, splashing our way upstream through torrents of hearsay, cross-fire and garbled paraphrases of the views 'Settlers and Colonists' is said to express. For much of the chronology below it will not be entirely clear what lies at the source of all this froth and thunder - that is, what Gray actually wrote. This seems to me appropriate: it is precisely how the controversy unfolded, and how it should be documented as an episode in Gray's public life.

For a more detailed account of the same events, including links to dozens of news stories, essays and social media comments not cited below, see the online archive listed in the bibliography under Hames 2013b. There is too much material to cover adequately here, even in paraphrase, though I urge interested readers to seek out the longer and more thoughtful essays on 'Settlers and Colonists' which appeared after the period chronicled below. A list of recommended sources appears toward the end of this chapter. Because the media 'framing' of this episode (and its impact on Gray's public standing) were firmly established in the first week of the controversy, I concentrate on that period here, and leave my own reflections and speculations mainly to the end.

\section{WHAT HAPPENED?}

In early 2012 I invited Alasdair Gray, alongside 26 other Scottish writers, to contribute an essay to a collection entitled Unstated: Writers on Scottish Independence. Gray was an obvious choice for an anthology intended to resist the narrowing of the independence debate by pollsters and politicians, while endeavouring 'to document the true relationship between the official discourse of Scottish nationalism, and the ethical concerns of some of the writers presented as its guiding lights and cultural guarantors' (Hames, 2012, p.9-10). Gray is unmistakably one such writer, frequently and willingly embroiled in political debate, though not always on terms of his own choosing. To quote the introduction, 
The idea for this book assumed that prominent Scottish writers would feature in the rhetoric of both official campaigns, but also that the views of individual writers would be managed, 'storied', inflated and filtered in various distorting ways. (Hames, 2012, p.11)

This assumption was confirmed even before the book was officially published. On my arrival at the book launch party I discovered that Gray's essay would be debated on television later the same evening. Even before the writers could be heard on their own terms (our main objective), highly mediated versions of what they had written were crowding them out.

\title{
SUNDAY 16 DECEMBER
}

The day before, Scotland on Sunday ran a story by Tom Peterkin headlined 'Alasdair Gray attacks the English for "colonizing" arts'. (In online editions this was later amended to drop 'the' from 'the English'.) Its opening paragraphs read as follows:

\begin{abstract}
ALASDAIR GRAY, one of Scotland's most respected authors, has launched an attack on the appointment of English 'colonists' to influential and powerful positions in Scotland. In a critique of English immigration north of the Border, the writer says the largest influx of new residents into Scotland can be split into either long-term settlers, whom he approves of, or short-term colonists who come north to advance their career. Gray's anger is directed mostly at senior arts administrators, saying that is his area of expertise, but he adds: 'I think Scottish folk in other professions will know settlers and colonists with similar attitudes.' As examples of colonists he names Vicky Featherstone, the former artistic director of the National Theatre of Scotland, and a number of other senior managers working in the arts field, whom he accuses of downplaying Scottish talent. Gray, 77, concedes that some of his remarks may suggest an 'anti-English prejudice' but adds that it must be remembered that 'these colonists were invited here and employed by Scots without confidence in their own land and people'. (Peterkin, 2012a)
\end{abstract}

Reaction to this story was swift and intense. Within hours dozens of politicians, celebrities and members of the public had expressed their dismay via social media. For opponents of Scottish independence, Christmas had come early. A Conservative member of Stirling council was quick to seize on Gray's long association with nationalism - Gray's artwork featured on First Minister Alex Salmond's 2011 charity Christmas card - in a tweet clearly intended to spread the mounting ordure from Gray to the Scottish National Party. 'Alasdair Gray's outrageous comments on English colonialism epitomize the ugly face of Scottish Nationalism. Parochial, xenophobic, inadequate' (Callum Campbell, 16 December 2012). More significant politicians continued in this vein, loudly condemning Gray's reported comments and seeking to embarrass the cause with which he is associated. By lunchtime on the day the Peterkin story appeared, members of the (UK) Shadow Cabinet were castigating the SNP's guilty 'silence' over the Gray story. The Shadow Foreign Secretary, Douglas Alexander MP, began a Twitter exchange with Scotland's Deputy First Minister, Nicola Sturgeon MSP.

@DAlexanderMP: Just days ago@NicolaSturgeon quoted Alasdair Gray in making her case for nationalism- so why today is there only silence from SNP? \#indyref

@NicolaSturgeon: @DAlexanderMP either you missed the SNP quote in the article or you are choosing to ignore it as it doesn't suit your purposes? Which is it?

@DAlexanderMP: @NicolaSturgeon the quote you're hiding behind doesn't even make reference to Gray's language. Will you now disassociate yourself with it?

@NicolaSturgeon: @DAlexanderMP I stand for a progressive, welcoming, civic nationalism and u know it. The smear attempts are beneath you. Enjoy rest of wknd.

@DAlexanderMP: @NicolaSturgeon thanks. The SNP leadership's unwillingness to speak out clearly on this tells me all I needed to know. Have a good weekend. 
There is a clear effort here to convert Gray from a rhetorical asset to a liability for supporters of independence. More telling, the SNP quote supplied to Peterkin, and Sturgeon's second tweet (regarding 'smear attempts'), seem to concede Gray's sudden reversal into a 'toxic' figure now anathema to responsible (or at least 'progressive') political discourse. Sturgeon refers to careful quotes from an English-born SNP MSP (included in the original Peterkin article), effectively dismissing Gray's reported views without overtly condemning them: 'Just as the world has benefited tremendously down the generations from the skills and ingenuity of global Scots, Scotland has been hugely enriched as a nation through those who have come here to live and work and raise their families - from England and further afield'. If the whole of his argument in 'Settlers and Colonists' had featured in the controversy at this early stage, it would be obvious that this quote is closer to a paraphrase than a rebuttal of Gray's stated views.

Writers, artists and cultural figures were also highly vocal in the opening stages of the controversy. On Twitter the novelist Irvine Welsh, playwright David Greig, and critic and filmmaker Mark Cousins expressed their disappointment and even 'heartbreak' at Gray's reported remarks. The Glasgow musicians Stuart Braithwaite (Mogwai) and Alex Kapranos (Franz Ferdinand) expressed skepticism about Gray's alleged anti-Englishness (drawing on the Peterkin story and their own knowledge of Gray's writing). I contacted Welsh and Cousins by email the afternoon of the day the story broke, suggesting that Scotland on Sunday had 'spun' an undoubtedly provocative essay. After reading 'Settlers and Colonists' Welsh quickly retracted his earlier criticisms of Gray and condemned the Peterkin article, tweeting: 'Thought it read too crassly to be Gray. Pathetic show SOS [Scotland on Sunday]'. Praising Kevin Williamson and Mike Small's more detailed critique of the Peterkin article the next day (see below), Welsh described the original story as a 'disgraceful \& spiteful piece of journalism from Scotsman publications which duped myself and others'. Mark Cousins was less impressed by the full essay, tweeting the following day: 'i just read full essay. its 1 st 2 pages $r$ good, but then it becomes disturbing 4 me. v UKIP'. ${ }^{2}$

By the evening of Sunday 16th I had joined Twitter in order to track the online reaction, and was attempting to resist the storm of under-informed comment. A copy of the essay was sent to Vicky Featherstone, who was made central to the controversy in a particularly cynical and unfortunate way - largely owing to the senseless rigidity of Gray's criteria for classifying 'settlers' and 'colonists'. I return to this topic at the end of the chapter.

Three initial observations: this all happened very quickly, and generated its own fevered momentum. (The exchange of tweets between Sturgeon and Alexander transpired inside 55 minutes.) Evidently the SNP were asked for comment as part of the original Peterkin story, and - it would seem - simply disowned any potentially damaging association with Gray, rather than querying his reported views. ${ }^{3}$ The press had decided Gray was toxic, and anyone linked to him was now required to disinfect forthwith. In the parlance of American scandal, Gray was 'under the bus' even before it left the garage. Second, only a handful of people had actually read 'Settlers and Colonists' by this point. As already mentioned, the Unstated book was launched the following evening; a few copies had been sold from the publisher's bookshop prior to the launch, and several review copies were in circulation among journalists. I also emailed copies to Welsh, Cousins and Featherstone. But at this point virtually all the reaction (including by senior politicians) is to an essay those commenting have not actually read. The Peterkin story is the only source of their strong opinions about 'Settlers and Colonists'. Third: the notion that Gray had voiced odious and bigoted views gained traction very quickly, and was treated almost immediately as a 'fact on the ground' rather than an assertion; a 'fact' about which ever more heated commentary became both possible and - to sections of the media - desirable.

\section{MONDAY 17 DECEMBER}

The front page of The Times (Scottish edition) reveals that 'SNP distances itself from Alasdair Gray over tirade'. The inside story quotes an unnamed spokesman: 'The Scottish Government disagrees with [Gray's] sentiments. Ministers stand for a welcoming and inclusive 
Scotland' (McIntosh, 2012). The frame of the story had been cemented, with Gray playing the villain of a Christmas pantomime. The deputy editor of Scotland on Sunday was evidently keen to keep the story on the boil, and took steps to maximize its emotive potential. That morning Kenny Farquharson tweeted:

@kennyfarq: \#AlasdairGray outburst means every English person going to work here this a.m. will look at workmates \& ask: 'Do they think I'm a colonist?'

Only the day before a leader in Farquharson's paper deplored Gray's 'unhelpful' and potentially 'divisive' rhetoric.

Over the next few days the editors of the pro-independence blog Bella Caledonia strongly defended Gray and highlighted his role in the development of modern Scottish nationalism. In their Monday piece Kevin Williamson and Mike Small began by sketching the climate following the surprise re-election of the Conservatives at the 1992 election (winning 11 of 72 Scottish seats). As the first sustained effort to defend or contextualize Gray's politics, it deserves to be quoted at length:

[From 1992] the concept of 'a democratic deficit' gathered political momentum and [...] Scots slowly but inexorably stirred, rose to our feet, and began to assert our right to exist as a self-governing nation. Into this cauldron of questioning and cultural renaissance author Alasdair Gray published an incendiary pamphlet titled Why Scots Should Rule Scotland. In the first few sentences of Chapter 1, 'The Scots and Where They Come From', Gray laid down a marker:

'The title of this book may sound threatening to those who live in Scotland but were born and educated elsewhere, so I had better explain that by Scots I mean everyone in Scotland who is able to vote.' He continued: 'My definition cheerfully includes many who think themselves English but work here as hoteliers, farmers, administrators and directors of Scottish institutions.'

He generously included as Scots the Dukes and other great landowners who have stately homes and property in many other countries.

Some may think this definition of a Scot both too liberal and too narrow, but I believe that every adult in a land should have equal say in how it is ruled so therefore belongs to it, however recently she or he arrived.' Adding, as a reminder, lest we need one: 'The first people who called themselves Scots were immigrants.'

The influence of these few paragraphs cannot be overstated. Alasdair Gray defined civic nationalism for a generation and his definition of 'a Scot' could not have been more inclusive and welcoming, nor further away from inward looking ethnic nationalism. In this respect Gray, as much as any one individual, helped shape the modern Independence movement as it is today. Thanks in much part to Alasdair Gray our independence movement has no place for racism or anti-Englishness. It has inclusiveness and the welcome at its heart. [...] Fast forward 20 years and Scotland on Sunday run a story under the provocative headline: 'Gray attacks the English for 'colonizing" arts.' The sub-header is equally provocative: 'Writer claims incomers are exploiting Scottish culture'. Before anyone read his essay the social media mobbing of Gray began, braying for his head. [...] This is a deliberately poisonous interpretation of Gray's words. Far from having a pop at incomers as SoS dishonestly claim, Gray's thoughtful historical essay lauds the efforts of people who have arrived here in Scotland and have contributed to and enriched our arts, culture and society. The substance of Gray's essay is to ask why such a disproportionate number of people in senior administrative positions in the arts are not Scots (in the broad inclusive definition given above) and whether this is having a negative effect on Scottish culture. This is an important question. (Williamson and Small, 2012) 
As noted, the essay was discussed on television hours after the book launch in Edinburgh. Two respected figures in the Scottish cultural world, actor Tam Dean Burn and festival director Hannah McGill, debated the essay on STV's political programme Scotland Tonight. Both had been supplied copies of the essay, and knew what they were talking about. While both were critical of Gray's argument and use of the terms 'settler' and 'colonist', the tone of their discussion was notably measured compared to the reactions noted above.

\section{TUESDAY 18 DECEMBER}

Gray's initial response - denying anti-Englishness - is trailed on the front page of the Glasgow Herald. In the inside story Gray says 'the row had left him mystified'.

He added: 'I do include in the essay that I thoroughly approve of settlers but I might regret colonists. I was using the words with great care, I am a professional writer you see, and I explain in the essay why I used them. I think any kind of writer who was afraid of saying something that they believe, because it would cause annoyance, would be very silly.' (Miller, 2012a)

\section{WEDNESDAY 19 DECEMBER}

The next day, Scotland's leading historian 'said Gray's language and opinion [...] was disgraceful and not an apt description of the English population in Scotland or its contribution to Scottish society' (Miller, 2012b). I later established that Professor Tom Devine was not entirely happy with the Herald journalist's presentation of his comments; the journalist admitted not having read 'Settlers and Colonists' himself. On the same day, the Scottish leader of the Liberal Democrats, Willie Rennie, argued that Gray's comments 'run the risk of giving an air of respectability to the repugnant actions of [...] racists' (Hjul, 2012). In the Daily Telegraph Jenny Hjul compared Gray's 'odious language' to government efforts 'to try to silence British "colonists" in apartheid South Africa, and insinuated that Gray's 'Anglophobia' and 'intolerance' exposed the true nature of Scottish nationalism:

SNP politicians are quick to distance themselves from any hint of discrimination against their neighbours, but there is no denying that the belligerent nationalism stirred up by Alex Salmond, the First Minister of Scotland, has given his less restrained supporters a licence to preach hatred. (Hjul, 2012)

Hjul worried 'that if Scotland's undercurrent of anti-Englishness is exploited now for political gain it will leave a lasting legacy long after the referendum is over' (Hjul, 2012). But which side of this argument was exploiting (claims of) anti-Englishness for political gain? In a further blog for Bella Caledonia Kevin Williamson highlighted a rash of news stories asserting anti-Englishness in Scottish culture, and examined their function with reference to Chomsky and Herman's 'propaganda model'. Williamson condemned the original Peterkin article as a 'smear', and its publishers of 'playing the anti-English race card as they attempt to drag Scottish political life down to the gutter'.

That it has been firmly established that Alasdair Gray doesn't have an anti-English bone in his body is well known, but for the Unionist media this is neither here nor there. The individuals don't matter when framing a poisonous meme. The objective is all about getting the words 'anti-English' into common currency and equating them with the Independence movement. (Williamson, 2012b)

Williamson was partly addressing a second wave of heated reaction to his own remarks on Twitter the day before, asking why the issues raised by 'Settlers and Colonists' should remain taboo. 'Time has come for a social audit of institutional Scotland. Who are these people? Who do 
they speak for? What class, demographic, ethos?' A series of articles furiously condemned Williamson and highlighted his links to official pro-independence campaign groups. Williamson withdrew the phrase 'social audit', conceding that it could have sounded 'fascistic'. For several days this became a spin-off controversy running alongside 'Settlers and Colonists'. If any other public figure was thinking of defending Gray, or attacking his attackers, the fallout from Williamson's remarks would have given them pause (see Gilbride, 2012 and Wade, 2012).

On the same day, Bella Caledonia published a thoughtful blog by the journalist and broadcaster Lesley Riddoch reflecting on the debate and its deeper context:

Until Scots believe in their heart of hearts that they are leadership material - just as they are the sensitivity surrounding Scots and Scottishness in top places will endure. The terrible shame of the last few days is that the piece by Alasdair Gray hasn't served to open up debate but make it too angry and hurt to even air. Ochone. (Riddoch, 2012)

It is important to acknowledge the genuine hurt caused by the essay, only part of which can be attributed to the way it was reported. The writer and activist Alastair McIntosh wrote a long and thoughtful comment in response to Riddoch's blog, examining the personal and emotional dimension of the issues Gray had broached.

It's such a fraught subject. I speak as one who was born in England of an English mother and a Scots father, and lived there for the first four years of my life, and was very much seen as 'English' when I first went to school and until I fully discovered, only in my twenties, my Scottish identity. The fact is that in the arts, the environment, and very much so in landowning and the control it exerts, there is a dominance of either English folks or of Scots who have been to Anglicised public schools [...]. There are also quite a few Americans. Does this matter? Yes, but as I see it, not because of where they come from. As I see it, it matters for cultural reasons. For nearly 9 years now I've lived in Govan. It saddens me to see young people who would flourish elsewhere literally self-harming with knives (I have one young woman in particular in mind) because she feels so ashamed of being from Govan. What makes her like this, I ask my self? It's not the English, or the Americans, who feature strongly in the arts world that interests her. But it is about cultural differences. It is about generations of what Frantz Fanon (in The Wretched of the Earth) called 'inferiorisation', and what Paulo Frieire (in Pedagogy of the Oppressed) called 'cultural invasion'. [...]

There are English people working with poverty here in Glasgow - Bob Holman is a famous example, Gehan Macleod (nee Ibrahim) at the GalGael Trust is another - who have led things and totally belong, because they see behind these issues of class, and use their gifts to stand in solidarity with those who have so little. Give us more such English people. But take away this poison of any sense of social class superiority. Take it away, also, where it appears in Scottish nationalism. There is only one question that counts. Where do you stand? Are you with those who are on the make? Or are you where the suffering is? As a Latin American poet said. 'Solidarity is the tenderness of the people.' I'm sorry to have gone on. Alasdair Gray has had the courage to raise a deep issue. I hope that those he has hurt might sit with it, and work it through, and come to see that there is potentially healing for us all in this. (McIntosh, 2012)

\section{THURSDAY 20 DECEMBER}

Several items in The Scotsman move the debate along, building on the more reflective and analytical responses emerging the day before. The first adds John Byrne to the list of celebrated Scottish artists 'condemning' Gray's remarks - though whether Byrne had read the full essay is unclear (Ferguson, 2012). An editorial from Bill Jamieson restored perspective to the central argument of 'Settlers and Colonists', beginning with the suggestion that the 'fusillade of criticism' directed at Gray had been excessive. 
Let us all agree that there is no place for bigotry; that considerations of merit and appropriateness should be paramount in the selection of candidates for positions in Scottish life, and that these positions should never be closed to applications from outside Scotland. Let's also, this being the season of goodwill, spare comparison of Mr Gray's views to apartheid South Africa. He has not, to the best of my knowledge, proposed restricting the movement of English people into Special Areas, still less herding them permanently into bantustans. What he has done is to remind us, if rather more bluntly than some of his own admirers would wish, that Scotland is more than a place. It is an idea. Our writing, our language, our values, our history, our culture are not identical to those in the rest of the UK. There may be features that we share and enjoy in common. But Scotland is not England. To approach appointments in Scottish life and letters as if these were identical to and requiring no differentiation from appointments in the English regions is a misjudgment. And there are dangers in allowing appointments to our artistic and cultural institutions to be approached as if they were indeed little more than short-term staging posts to something better elsewhere, an en passant opportunity to add another notch to that (hired) gun. [...] We have a history to honour and a distinctive culture to respect. And it's in the defence of these that I say: Vive Alasdair Gray; Vive la difference. (Jamieson, 2012)

In a third Scotsman article Andrew Eaton-Lewis helpfully traced the explosive combination of two separate stories concerning anti-Englishness in Scottish culture, the linking of which was invited by Gray's (seemingly reluctant) reference to Vicky Featherstone (of which more below):

Read Gray's essay in full and you'll find, I believe, absolutely none of the anti-Englishness he has been accused of this week - despite his questionable use of words with such potent and negative historical associations. But his decision to label Vicky Featherstone, the popular departing director of the National Theatre of Scotland, as a 'colonist' was deeply unfortunate, given that the essay was published on the same day Featherstone said she had suffered from what she called anti-English bullying during her eight years in Scotland. Result: a perfect media storm, as the two stories became conflated and Gray's essay appeared to embody the anti-Englishness Featherstone had experienced. (Eaton-Lewis, 2012)

On the same day a letter from Gray is published in the Glasgow Herald:

I was surprised and entertained by reactions to a recent news report (not in The Herald) accusing me of Anglophobia. It criticised my essay, 'Settlers and Colonists', in a collection of essays by many writers about challenges to Scottish independence. Those wanting that are often called Anglophobic, just as those wanting Britain out of NATO are called Americahaters, and those criticising Israel's war in Palestine are called anti-Semitic. My essay is not Anglophobic, though two or three of my sentences quoted out of context suggested that. Those who want to know what I carefully wrote should buy Unstated (published by Word Power Books) or read it on www.word-power.co.uk. (Gray, 2012b)

Having confirmed that Gray wished the essay to be made available online, 'Settlers and Colonists' appeared on the publisher's website the same evening. Up until this point, the publishers and I had been guided by Gray's own sense of bemusement about the affair, and indifference to those who would judge him without reading him. From this point on, there was no excuse to comment on 'Settlers and Colonists' without actually reading it (for free, online). I added a brief explanatory note:

In five days many outlandish things have been said and written about [this essay] (chiefly by people who have not read it), and the author has been widely derided for the views it is said to express. Very recently, more edifying and reflective debate has begun to emerge. [...] There 
is no doubt that this essay, viewed 'within context' and free of distortion, is provocative. Many dismayed reactions to news reports about this essay will apply to the essay itself. So long as we are debating what Gray actually wrote, and not something else, so be it. I do not think the essay is inflammatory or irresponsible in its rhetoric. [...] The burden of proof does not rest with Alasdair Gray to demonstrate that he is not a racist, an Anglophobe, a bigot, or a disgrace. A lifetime's worth of art is there to be examined for anyone who cares to look. The burden of proof rests with those describing the man and his work in such terms. (Hames, 2013b)

\section{FRIDAY 21 DECEMBER}

On his Blood and Porridge blog Ian Smith compiles an early and useful overview of the media reaction outlined above, patiently explaining what would be self-evident to anyone who had actually read 'Settlers and Colonists': 'One: When Gray talks about English "settlers" in Scotland, he means it as as a compliment' (Smith, 2012). Smith also sketches the important context of recent controversy at Scotland's national arts funding body:

Gray's comments were certainly topical. The essay was written in the wake of the resignation of the chief executive at the Scottish arts quango Creative Scotland, Englishman Andrew Dixon, following a much-publicised letter of complaint signed by 100 leading lights in the Scottish arts world. The signatories included Gray and fellow-writers Janice Galloway, James Kelman, AL Kennedy, Bernard McLaverty and Ian Rankin, poets Liz Lochhead and Don Paterson, playwrights John Byrne and David Greig, composer James Macmillan and singer Karine Polwart. Their letter condemned in Creative Scotland 'a confused and intrusive management style married to a corporate ethos that seems designed to set artist against artist and company against company in the search for resources'; and called for, among other things, assurances 'that funding decisions are taken by people with artform expertise'. 'The appointed director,' observed Gray in his essay, 'was not Scottish, admitted to knowing nothing of Scottish culture, but said he was willing to learn. Ain't Scotland lucky?' (Smith, 2012)

Gray's essay was received by a Scottish artistic community highly adrenalized by recent protest concerning cultural management, and generally pleased by its success in forcing change at the top. The residual sense of unity (Dixon's resignation was announced on 3 December) made the divisive impact of 'Settlers and Colonists' all the more salient. The quasi-mutiny against Creative Scotland had nothing to do with anti-Englishness (as far as I can see), but as Smith notes Gray's essay did highlight the director's nationality and question his suitability on grounds of cultural expertise. (Dixon is not mentioned by name, but does not need to be.) Note that Gray's essay was written well before any open challenge to the management of Creative Scotland, or Dixon in particular; another essay from Unstated by the poet Don Paterson fired the starting-pistol for the wave of complaint and petitioning which led to Dixon's resignation when it was published in the Glasgow Herald on 14 September 2012.

\section{SATURDAY 22 DECEMBER}

With newspapers saving their weightiest comment pieces for Sunday editions, Gray-gate takes a short breather. A thoughtful letter to The Scotsman casts light on the debate and Gray's use of terms:

My own tuppence worth in this synthetic little spat would simply be that, in using the term 'colonist' Mr Gray was incorrect in a purely semantic sense. The more appropriate word would have been 'sojourner'. A colonist is an individual engaged in the policy-driven expansion of a particular imperium in another land, where all the apparatus of state is deployed for the furtherance of the mother country's colonising objective. A sojourner is 
simply a person from somewhere else who, of their own volition, chooses to spend part of a career in a land other than their own with the intention of going back home some day. [...] The contribution of many sojourners can be entirely positive. Vicky Featherstone's tenure at the National Theatre of Scotland is a case in point, and is in the best theatrical 'sojourner' tradition, which began when Jim Haynes, among others, founded the Traverse Theatre [in Edinburgh] in the 1960s. I don't think Jim was colonising for Louisiana, though he certainly helped to release us from the gloomy crypto-Calvinist bondage which then characterised cultural life in Edinburgh outside the Festival. (Black, 2012)

Having been tipped (by various journalists' enquiries) that the affair would plumb new depths the following day, a few commentators (on quite different 'sides' of the Gray controversy) attempted to calm matters, and to steer the discussion away from dubious charges of racism. Tam Dean Burn - who had been outraged by Gray's labeling of Giles Havergal as a colonist who 'for thirty-four years produced excellent plays that drew full houses, only two of them plays by Scots with Scottish settings' (Gray, 2012a, p. 106) - tweeted:

@tamdeanburn: Folks the Alasdair Gray stooshie is going to get more poisoned tomorrow so its vital we now try heal \& attempt a united front- see next $>>$

@tamdeanburn RT or QT I don't believe Alasdair Gray is racist or anti-English \#yesornoletsmoveon

\section{SUNDAY 23 DECEMBER}

Scotland on Sunday devotes the cover of its arts and review supplement to a photograph of Gray above the stark headline 'Settler watch'. When challenged, Kenny Farquharson takes personal responsibility for the headline, which many find highly objectionable. 'Settler Watch' and 'Scottish Watch' were fringe groups active in the 1990s which

campaigned against migration of so-called 'white-settlers' into rural parts of Scotland. Activities have included putting up threatening posters, leaving threatening packages with Celtic designs on doorsteps, and spray-painting slogans on houses with English occupants. It is important, however, not to inflate the significance of what have always been tiny fringe organisations; nevertheless their existence does highlight the prevalence of some anti-English feeling on the political periphery. (McIntosh, Robertson and Sim, 2008, p.97)

To associate Gray with this organization was, many felt, indefensible; particularly since Gray's essay uses the word 'settler' in precisely the opposite way implied by the headline (that is, as a term of praise and respect for 'incomers' whose presence has enriched Scottish culture).

In the same newspaper Andrew Wilson, ex-parliamentarian for the SNP, noted that Gray's essay had been linked to mis-reported statistics indicating a rise in anti-English racism in Scotland (when the reverse was true). Wilson condemned sensational media coverage and inveighed against those 'spreading damaging fiction about our society', but added his own hyperbole in veiled remarks about Gray:

Anyone in any position of leadership needs to take great care to avoid even an iota of legitimacy being given to arguments of intolerance and bigotry. It may not be their original intent but care must be taken to consider the implications down the line for what one word here can mean for pain there. Careless talk literally can and does cost lives. (Wilson, 2012)

In the same newspaper Dani Garavelli raised the temperature still further:

The 1990s were a savage time to be English in Scotland. It's difficult to recall now the level of vitriol those who moved north of the Border or bought holiday homes were subjected to. 
But, at the very time Mel Gibson was crying freedom in Braveheart, there was a war of sorts raging across the country. Groups such as Scottish Watch and Settler Watch, which intimidated southern incomers and the Scots who sold their properties to them, were at their strongest. English people were being attacked on the streets, their very accents a provocation to national pride... (Garavelli, 2012)

Gray was trifling with matters of life and death; indeed, 'a war of sorts'.

It would be irresponsible not to contextualize these claims. For his groundbreaking study Being English in Scotland, Murray Watson conducted 59 lengthy interviews with English migrants settled in Scotland, and investigated the impact of the rag-tag 'Watch' groups to which Garavelli refers. 'Examination of all the testimonies indicated that the activities of these groups, in spite of the media publicity some of them received, failed to impact upon or touch the lives of the contributors to any extent' (Watson, 2003, p.133). This finding emerged within a study where '94 per cent of the sample indicated that anti-Englishness was not a serious problem' (Watson, 2003, p.127):

Throughout the period under review, the media painted a picture of a climate of anti-English feeling. This was not the general experience of the contributors, nor was it evident from other sources. Studies from a number of social scientists, albeit they were mostly restricted to peripheral areas, essentially corroborated the findings of this study. That was not to say that tensions did not exist. There were low levels of anti-English feeling and exceptional extremist activity, but the latter was largely directed against England, the state, and not English people. Compared with prejudicial reactions to other migrant communities, the English were largely welcomed into Scottish society, and this is certainly borne out by the constant growth of English migrants settling in Scotland. (Watson, 2003, p.188)

Watson also examines 'the role of the media in generating and/or exaggerating antiEnglishness' (Watson, 2003, p.143). I agree with Watson that this topic is worthy of further research.

In the Guardian, Kevin McKenna strongly argued that 'Gray's essay is not in the slightest anti-English':

The settlers and colonists referred to in the title of Gray's essay are some English senior administrators who have flourished in Scottish public life, principally in the arts, and whom he holds responsible for a failure to 'help creativity shine at home and abroad', an epithet contained in the lofty mission statement of Creative Scotland. Gray constructs a thesis that draws important distinctions between 'colonists' and 'settlers'. Colonists are characterised by their refusal to engage fully with Scotland, accompanied by a demonstrable aversion to promoting indigenous Scottish art; settlers by their long-term commitment to Scotland and an eagerness to stimulate growth among Scottish artists. For venturing such an opinion, Gray has been branded a 'disgrace' and stands accused of being 'anti-English' and fomenting racism. [...] Alasdair Gray's essay elegantly and succinctly introduced a crucial question that Scotland must debate: how important to the health and wellbeing of the nation is it to provide the means and the opportunity to express ourselves artistically and culturally? (McKenna, 2012)

McKenna's précis raises an awkwardness for those inclined to defend 'Settlers and Colonists' (and, indeed, those insisting on the author's own words): it makes Gray's point rather better than he does, and without leaving dozens of hostages to fortune.

On the front page of the Sunday Herald, a large photograph of the eminent Glasgow writer James Kelman, Gray's long-time friend, appears above the quote 'The English may be fine people 
but they are in control of Scottish culture and they don't understand it'. This statement is clearly presented within quotation marks, but appears nowhere in the article inside.

'Even to assert that we do have a literary tradition of our own is somehow to be seen as a form of anti-Englishness or xenophobia or racism [...] In any other country in the world imagine we were in Norway - how would it be if we were Norwegian people and the people who controlled all our artistic endeavour and expression were people from Denmark and their only education experience was Danish? Danish art, Danish music, Danish literature. And yet they're [the English] in control of ours'. [...] On a personal level, says Kelman, he has nothing against the likes of the former director of Creative Scotland Andrew Dixon and outgoing National Theatre artistic director Vicky Featherstone. 'On the contrary. They are really nice people. It just hasn't dawned on them that Scotland's a country.' (Taylor, 2012)

Many other comment pieces appear the same day, with the most outspoken imagery and commentary in the right-of-centre broadsheets, fully exploiting the episode's potential to tarnish arguments for independence. Memorable is a large photograph of Gray in the Sunday Times (Scottish edition), under the thundering headline 'FREE-DUMB'. But I will finish this chronology with a series of more reflective comments by David Greig from the same day:

@DavieGreig: I know we all have better things to do than read yet more about 'Settlers' and 'Colonists'. I found it all a bit heartbreaking at first -

@DavieGreig: But I'm coming to believe perhaps these debates/ fears/ hopes/ angers were under the surface ready to burst - and so maybe it's been good -

@DavieGreig: Self confidence comes partly from a sense that one's cultural background is given back to you in art. People anywhere deserve that.

@DavieGreig: But Scotland does not have a monolithic single culture. It is - as Gray so memorably put it - an archipelago of cultures.

*

$*$

*

$*$

'I met many reporters when I was chaplain at Barlinnie Jail and on average they're no more wicked than other people. But their job depends on being entertaining, so they make everything look as clownish or as monstrous as they can. If any more reporters come, Duncan, my advice is to tell them nothing you really feel or believe.' (Gray, 1981, p.327)

There is not space here even to summarise many more searching and thoughtful responses that emerged after this initial week of news coverage. Particularly worth reading are the essays listed in the bibliography by Alan Bissett, Christine Hamilton, Pat Kane, Robert Livingstone, Mhairi McAlpine, Harry McGrath, Johan Sandberg McGuinne, Stewart Sanderson, Rory Scothorne and Adam Tomkins. Several of these essays argue 'for' and 'against' Gray's essay in terms not reflected in the initial news coverage above; of particular interest are Hamilton and Livingstone's essays challenging Gray's portrayal of the Scottish theatre scene in the 1980s (and especially the work of Chris Carrell), Tomkins' account of working with Gray on How We Should Rule Ourselves, and Kane's observations on the networked outrage that fuelled the controversy online. A few months later two public events focused specifically on the issues raised by 'Settlers and Colonists', allowing Gray to fully explain and debate the essay with an audience invited to ask questions (Tron Theatre, 9 May 2013; Edinburgh International Book Festival, 14 August 2013). The (UK) Shadow Secretary of State for Scotland, Margaret Curran MP, used Gray's 'profoundly wrong' remarks at the latter event - accusing the BBC of 'Scotophobia' - to re-toxify Gray and insinuate a sinister edge to the SNP's case for independence: 'While Gray's comments may have been presented as a point about the safekeeping of our national institutions, it was a deeply political point that threw light on a part of the independence debate that few seem to want to expose and many are reluctant 
to address directly' (Curran, 2013). Similar re-hashings of 'Settlers and Colonists' emerged in reports on the appointments of Laurie Sansom and Janet Archer (both English) as successors to Vicky Featherstone and Andrew Dixon as, respectively, Artistic Director of the National Theatre of Scotland and CEO of Creative Scotland. Asked for his reaction to Archer's appointment, Gray opined 'It would be nice if she became a Scottish settler and decided this was going to be her home. I think she will turn out to be another colonist' (Wade, 2013). It seems likely that Gray's essay will be cited whenever senior appointments are made in the Scottish arts for some time.

\section{REFLECTIONS AND SPECULATIONS}

- Is 'Settlers and Colonists' anti-English?

No.

- Why did Gray have to get personal, or name Vicky Featherstone?

It is true that Gray names names; this gave me pause when I first read the essay in draft form.

But I was and remain convinced by the reasoning in the background of this passage:

Said Scott Fitzgerald, 'Start with an individual and you may end up with a type. Start with a type and you may end up with ... nothing'. I will speak of individual immigrants known to me. Because I am a writer in Glasgow they are all associated with literature and the arts, but I think Scottish folk in other professions will know settlers and colonists with similar attitudes. (Gray, 2012a, p.104)

Gray is writing from his own experience, and emphasizing the locality of the personal 'evidence' from which he will make much larger judgments (accompanied, typically, with a compressed polemical history of Scottish arts administration). Perhaps the gap between Gray's anecdotal cases and those more sweeping statements is too large. I still feel it would have been far more provocative, and even irresponsible, to make the argument Gray wishes to make without providing examples. It is certainly uncomfortable to see individuals (one deceased) fingered as 'colonists'; but it would be far worse to generalize about people from country X or profession Y, or to suggest with a wink 'you know the sort of people I mean'.

This brings us to the case of Vicky Featherstone, who is mentioned just once in 'Settlers and Colonists', almost in passing. Writing several months before an official announcement, Gray notes that she 'may be leaving in 2013 for work nearer London. That is my only reason for thinking her a colonist' (Gray, 2012a, p.107). Note, first, that many other directors and administrators are discussed at greater length in the essay, also by name. Gray is scathing about the BBC but says nothing in criticism of the National Theatre of Scotland or Featherstone's work as its artistic director. Yet Featherstone is positioned as the primary victim of Gray's anti-English bigotry in the original Peterkin story, and in the vast majority of comment referring back to that story.

Note also that the essay turns on a firm - needlessly firm - division between 'settlers' who come to stay, committing themselves to Scottish culture, and opportunist 'colonists' whose 'work for institutions originally created to encourage art in Scotland actually depressed it' (Gray, 2012a, p.106). By the terms Gray has constructed, everything depends on where the migrant to Scotland ends up - if that is 'back in England through promotion or by retirement' (Gray, 2012a, p.104), such a person is ipso facto not a settler (who comes, stays, puts down roots), and must therefore be a colonist. The southbound Featherstone falls into this category only as a function of Gray's rigid system; such is my reading of the tacit import of Gray's 'only reason'. The Scotland on Sunday story omits this nuance, clear to any reader of the essay, presenting Featherstone as Gray's archetypal colonist rather than a sort of regrettable problem case. But if Gray detects the weakness of his dichotomy here, why doesn't he soften or refine it? I cannot speak for the author, but as a fan I recognise the strong hard lines of the murals and the seductive, disarming briskness of Gray's political and historical schemata. In Gray's art such crisp divisions often have a generative and critically illuminating function, in addition to their reductively classificatory one; but not in 'Settlers and Colonists'. 
- Aren't the terms themselves unfortunate, even irresponsible? 'Settlers?' 'Colonists?'

From the earliest stage of the controversy, most commentators inclined to defend Gray from the media onslaught baulked at his choice of terms. A tweet by Lesley Riddoch captures the unease engendered by 'settlers' and 'colonists', and the sense of these labels both distracting and detracting from Gray's valid argument:

@LesleyRiddoch: Re Al Gray in SOS, there's no question Scots are under-rep @ top level of arts environment \& civil service. Never mind settler/colonist tags. (16 December)

But Gray is quite deliberate about these terms and does not resile from them, neither in the essay (see the title) nor in subsequent commentary (insisting he used them 'with great care'). 'Colonist' is obviously contentious but the real difficulty arises with 'settler'. Evidently Gray expects readers to consider his own definition of this term, as explained in the essay itself, and seems either unmindful of its connotations outside the essay (which range from the neutral to the xenophobic), or perhaps minded to re-code or 're-claim' the word (as positive). This may be a generous reading; the impetus of the essay is clearly more to challenge 'colonists' (and the pattern in Scottish culture which, according to Gray, miserably defers to colonists) than to celebrate 'settlers'.

What is clear is that Gray's use of settler is impossible to mistake for the rhetoric of 'Settler Watch'. He begins by characterising migration as the good and natural condition of human civilization - 'A Scottish wordsmith said, "Outgoers and incomers made, make every land". Yes' and spends a considerable portion of the essay in praise of 'settlers here who became more effectively Scottish than most born natives', noting the vital contributions of English, Cornish and Welsh incomers to the revival of Scottish culture in the twentieth century (Gray 2012a, p.100 \& 108-10). Having hymned the labours of Edward Dwelly, Timothy Neat, David Knowles and Sharon Blackie, Gray adds 'I do not know or care if the true settlers I have mentioned will vote for Scottish independence in the 2014 referendum, as I certainly will. Their work here is good for us' (Gray, 2012a, p.109). Almost none of this was reported in the initial phase of the controversy. The Peterkin story entirely omits Gray's praise of individual 'settlers', and the first burst of commentary relied entirely on Peterkin's account of 'Settlers and Colonists'. (The essay discusses, by name, five colonists and five settlers; as discussed above, Andrew Dixon makes an unnamed sixth colonist. Only Featherstone is mentioned by Peterkin.) On several occasions the media exploited the charged nature of 'settler' in ways that obscured Gray's 'good/bad' binary, presenting 'Settlers and Colonists' as two negative slurs.

But even if we read 'settlers' by Gray's own definition, there is an absurd quality to this dichotomy. Migrants moving to Scotland can be one of two things, and that thing depends entirely on where they wind up (at death?) since to leave Scotland is to relinquish settlerdom and its exculpatory power. Featherstone's colleagues in the world of theatre, film and television were quick to highlight the inanity of this model when applied to the real working conditions of Scottish actors, writers and directors, the vast majority of whom simply cannot survive on Scotland-based work. There is an additional frisson of discomfort in the notion that only those immigrants who fully naturalise, becoming 'effectively Scottish', qualify for this honour.

- This has all been very awkward and painful.

When I first began charting reaction to 'Settlers and Colonists' it was obvious that political point-scoring and media outrage-mongering lay behind the initial frenzy, the emotion of which seemed largely synthetic. But over time it became equally obvious that many people were genuinely hurt by the essay, and/or by the media coverage around it. This topic provokes a kind of brittleness in many areas of Scottish life, and I have, for example, seen English colleagues visibly wince when they casually scan some of the newspapers lying around my office (and cited above). There is a difficult and almost unspeakable subject here, worthy of careful exploration. 'Settlers and Colonists' is by no means Gray's finest piece of political writing, but its potential to upset and offend was cynically exploited. 
A documentary film on Gray's life and art will be released in 2014. I understand the filmmaker elected not to include the 'Settlers and Colonists' furore, having determined that it cast little light on his subject. This seems right to me. This saga revealed far more about the cultural, political and media environment in Scotland than about Gray himself. The pitch and profile of this controversy had everything to do with the independence debate, and its weekly churn of smear and counter-claim. A few weeks after the period of intense commentary outlined above, the leader of the Better Together campaign (against Scottish independence) 'warned that some people will make it their "mission" to create divisions as the temperature rises in the battle for Scotland's future'. In a clear allusion to the Gray affair, Alasdair Darling noted that 'the year ended with dangerous and divisive language entering the independence debate' (Peterkin, 2012b). Political advantage was being extracted well into 2013, as we saw in the Margaret Curran remarks in August. As Ian Bell wrote, 'Anti-Englishness is far too handy a cudgel to be laid aside in the political struggle with Nationalism' - adding 'but it has nothing to do with Gray's argument [in 'Settlers and Colonists']' (Bell, 2012).

- What does this all add up to?

A meaningless poll on the website of Scotland on Sunday asked 'Do you agree with Alasdair Gray that English immigrants to Scotland can be divided into "settlers" and "colonists"?' On 26 December 2012, 64\% of 1738 votes answered No. By 2 January 2013, 61\% of 6081 votes said Yes. - Will this saga have an effect on the independence referendum in 2014?

Taken by itself, almost certainly not. But 'Settlers and Colonists' has been constituted as a prominent 'case' in a larger political narrative hinting at something dark and shockingly backward just beneath the sunny and progressive façade of Scottish nationalism. The effectiveness of that wider story cannot be discounted.

- Has 'Settlers and Colonists' had a practical impact in the arena of Scottish arts administration?

The essay may have been an awkward presence in the minds (if not the outward discussions) of recent hiring panels for major arts organisations, but I suspect the overwhelmingly negative media reaction to 'Settlers and Colonists' has worked to close rather than open the issue it raises. It was Gray, rather than leading arts bodies, who was placed under pressure and forced to account for his values and decisions. No one has seriously suggested devising hiring policies that would prevent the 'colonist' scenario Gray portrays, and even were the principle not distinctly unpalatable to prevailing opinion, implementing it would be legally and practically impossible. (Tests of Scottish cultural knowledge? Promises to maintain Scottish residency?) But 'Settlers and Colonists' has also raised questions about leadership and representation Scottish cultural institutions will find difficult to ignore over the long term. This Sunday Herald leader shows the impact of Gray's core argument even while eschewing its terms and the possibility of 'anti-colonist' feeling:

So where should the debate go from here? Most certainly not to a pro-Scottish quota system or to a suspicion of those from outside Scotland who currently work here. But there is a case for fostering pride in the achievements of our artists and for creating a climate where new world-class works of art can be created and celebrated. (Sunday Herald, 23 December 2012)

\section{- What of the impact on Gray himself?}

What flowed from 'Settlers and Colonists' has perceptibly tarnished Gray's cultural standing and political capital. These developments are painful for Gray's many admirers and supporters; seemingly more painful than for Gray himself. But they may, in the long run, be no bad thing for serious Gray scholarship. If this episode has precipitated one sort of (temporary) Fall, it may have prevented another. 'Settlers and Colonists' seems to have arrested Gray's rise in middlebrow esteem to the petted status of a Rennie Mackintosh, even as the stretch of Glasgow's Byres Road between Ashton Lane and Oran Mor begins to take on the aura of a future 'Gray Trail' (or perhaps 'Gray Ramble'), attracting pilgrims and art-tourists visiting his murals, installations and fabled haunts. 
When Kelvin Walker returns from London to his native soil, a failed social climber (and reverse 'colonist'), his profile but not his opinions change accordingly. He becomes 'official spokesman for all that is most restrictive in Scottish religious and social opinion' and a fushionless placeman on public committees,

as a counterbalance to a succession of not very radical socialists. He counter-balances so successfully that the important public committees achieve little or nothing, and as this is what they are created to achieve almost everyone is satisfied. For a short while in the late seventies he looked as if he might put his weight behind a movement which nearly separated Scotland from the British Isles, but on second thoughts he left things as they were. (Gray, 1985, p.140)

Here the parallels with Gray end. At considerable risk to his own reputation, Gray has dared to raise very difficult and even painful questions of Scottish culture, in a political environment in which they were guaranteed to be unwelcome. In doing so he has probably sacrificed his own prospect of becoming a 'national treasure' uncritically beloved by all. Even if Gray enjoyed the attention and the outcry, that is not nothing. 'Settlers and Colonists' is not his most gallant contribution to Scottish cultural life, but the essay raises important and serious questions when Gray might easily have 'left things as they were' and retained his own comfort.

\section{BIBLIOGRAPHY}

Bell, Ian (2012) 'Why Gray was wrong to use the word settler', Sunday Herald, 23 December. Bissett, Alan (2013) 'Who Carries the Carriers?', National Collective, 6 June, http://nationalcollective.com/2013/06/06/alan-bissett-who-carries-the-carriers/, date accessed 21 December 2013.

Black, David (2012) 'Letters: Cultural understanding is crucial', The Scotsman, 22 December 2012. Bowditch, Gillian (2012) 'FREE-DUMB', Sunday Times, 23 December.

Curran, Margaret (2013) 'Nationalism is a cultural threat', The Scotsman, 21 August, $\mathrm{http}: / / \mathrm{www} . \mathrm{scotsman} . \mathrm{com} /$ news/margaret-curran-nationalism-is-a-cultural-threat-1-3054660, date accessed 21 December 2013.

Eaton-Lewis, Andrew (2012) 'The Year of Creative Scotland - a branding exercise overshadowed by controversy', 20 December.

Ferguson, Brian (2012) 'John Byrne insists Gray is wrong', The Scotsman, 20 December. Garavelli, Dani (2012) 'Proud of Scotland's melting pot', Scotland on Sunday, 23 December. Gilbride, Paul (2012) 'Tell us who is running our country', Scottish Express, 19 December. Gill, Kerry (2012) 'SNP to blame for any anti-English “colonist” jibes', Scottish Express, 18 December.

Gray, Alasdair (1981) Lanark: A Life in Four Books (Edinburgh: Canongate)

Gray, Alasdair (1985) The Fall of Kelvin Walker (London: Penguin)

Gray, Alasdair (2012a) 'Settlers and Colonists' in S. Hames (ed.) Unstated: Writers on Scottish Independence (Edinburgh: Word Power), p.100-10.

Gray, Alasdair (2012b) 'Letters: My essay was not Anglophobic, despite the impression given by the selective use of out-of-context passages', Glasgow Herald, 20 December.

Hames, Scott (2012) 'Introduction: Don't Feel Bought, You're Buying' in S. Hames (ed.) Unstated: Writers on Scottish Independence (Edinburgh: Word Power), p.1-15.

Hames, Scott (2013a) 'Responses to Alasdair Gray's "Settlers and Colonists", [Storify collecting online coverage and comment], http://storify.com/hinesjumpedup/alasdair-gray-does-not-do-twitter, date accessed 20 December 2013.

Hames, Scott (2013b) 'Editor's Note' accompanying online publication of 'Settlers and Colonists', http://www.word-power.co.uk/viewPlatform.php?id=610, date accessed 20 December 2013. 
Hamilton, Christine (2012) 'I wonder if anyone will ever realize how wonderful it all was, Christine Hamilton Consulting, 27 December, http://christinehamiltonconsulting.com/2012/12/i-wonder-ifanyone-will-ever-realise-how-wonderful-it-all-was/, date accessed 21 December 2013.

Hjul, Jenny (2012) 'Toxic “cyber nats" give the Scots a bad name', Daily Telegraph, 19 December. Jamieson, Bill (2012) 'Gray paints a fairer picture for us all', The Scotsman, 20 December.

Kane, Pat (2012) 'The Net, The Self and the Trouble With Scotland: on Alasdair Gray, and other matters cultural and political', Thoughtland, 24 December,

http://www.thoughtland.info/2012/12/unstated-critique.html, date accessed 21 December 2013. Livingstone, Robert (2013), 'Who’s Offended by Gray? I am', Scottish Review, 8 January, http://www.scottishreview.net/RobertLivingston45.shtml, date accessed 21 December 2013. McAlpine, Mhairi (2012) 'More on settlers and colonists', Second Council House of Virgo, 26 December, http://www.2ndcouncilhouse.co.uk/blog/2012/12/26/more-on-settlers-and-colonisers/, date accessed 21 December 2013.

McGrath, Harry (2012) 'Fade to Gray', Bella Caledonia, 30 December, http://bellacaledonia.org.uk/2012/12/30/fade-to-gray-2/, date accessed 21 December 2013. McGuinne, Johan Sandberg (2013), 'Alasdair Gray and the Settlers', Indigeneity, Language and Authenticity, 4 January 2013, http://johansandbergmcguinne.wordpress.com/2013/01/04/alasdairgray-and-the-settlers/, date accessed 21 December 2013.

McIntosh, Lindsay (2012) 'Author gets cold shoulder from SNP after English “colonists” jibe', The Times [Scottish Edition], 17 December.

McIntosh, Ian, Robertson, Douglas and Sim, Duncan (2008) English People in Scotland: An Invisible Minority (Lewiston: Edwin Mellen Press).

McKenna, Kevin (2012), 'Scotland should thank the English settlers', Guardian, 23 December Miller, Phil (2012a) 'Author Gray hits back at anti-English claims', Glasgow Herald, 18 December. Miller, Phil (2012b) 'Historian criticizes Gray over English claims', Glasgow Herald, 19

December.

Peterkin, Tom (2012a) 'Alasdair Gray attacks English for “colonising” arts', Scotland on Sunday, 16 December.

Peterkin, Tom (2012b) 'Darling urges respect in referendum debate', Scotland on Sunday, 30 December.

Riddoch, Lesley (2012) 'What connects Alasdair Gray, Dirty Dancing and Gary Tank Commander?', Bella Caledonia, 19 December, http://bellacaledonia.org.uk/2012/12/19/whatconnects-alasdair-gray-dirty-dancing-and-gary-tank-commander/, date accessed 11 December 2013. Sanderson, Stewart (2013) 'On its own terms: political sentiment in Scottish writing', Open Democracy, 1 May, http://www.opendemocracy.net/ourkingdom/stewart-sanderson/on-its-ownterms-political-sentiment-in-scottish-writing, date accessed 21 December 2013.

Scothorne, Rory (2012) 'A Very Grey Debate', National Collective, 24 December 2012, http://nationalcollective.com/2012/12/24/a-very-grey-debate/, date accessed 21 December 2013. Scotland on Sunday (2012) '[unsigned] Leader: Ill-chosen words', Scotland on Sunday, 16 December.

Smith, Ian (2012) 'In defence of Alasdair Gray', Blood and Porridge, http://bloodandporridge.co.uk/wp/?p=1072, date accessed 20 December 2013.

Sunday Herald (2012) '[unsigned] Leader: Tolerance and respect must guide nationality debates', Sunday Herald, 23 December.

Taylor, Alan (2012) 'James Kelman enters the Scottish culture controversy', Sunday Herald, 23 December.

Tomkins, Adam (2013) 'On the Nature of Scottish Nationalism', Notes from North Britain, 2 October, http://notesfromnorthbritain.wordpress.com/2013/10/02/on-the-nature-of-scottishnationalism/, date accessed 21 December 2013.

Wade, Mike (2012) 'Outrage over call for "social audit", The Times, 19 December.

Wade, Mike (2013) 'New Creative Scotland chief "is another colonist", The Times, 7 June. Watson, Murray (2003) Being English In Scotland (Edinburgh: Edinburgh University Press) 
Williamson, Kevin (2012a) 'Unanswered questions have been raised about Scotland's cultural institutions', Bella Caledonia, 18 December. http://bellacaledonia.org.uk/2012/12/18/unansweredquestions-have-been-raised-about-scotlands-cultural-institutions/, date accessed 11 December 2013. Williamson, Kevin (2012b) 'Spreading a despicable anti-English meme: The dirty war continues...', Bella Caledonia, 19 December. http://bellacaledonia.org.uk/2012/12/19/spreading-adespicable-anti-english-meme-the-dirty-war-continues/, date accessed 11 December 2013.

Williamson, Kevin and Small, Mike (2012) 'Why Alasdair Gray Matters (And Why He Must Be Smeared)', Bella Caledonia, 17 December. http://bellacaledonia.org.uk/2012/12/17/why-alasdairgray-matters-and-why-he-must-be-smeared/, accessed 11 December 2013.

Wilson, Andrew (2012) 'Debate on independence being muddied by unkind and unwise words', The Scotsman, 22 December.

\footnotetext{
${ }^{1}$ Nexis UK database, www.lexisnexis.co.uk/, accessed 12 December 2013. Note that 'Settlers and Colonists' accounts for the majority, but by no means all, of the press coverage in this period. Alongside reviews of recent publications, Gray's extraordinary civic engagement is reflected in news stories citing his support of a campaign against Glasgow City Council's plans to close daycare centres for people with learning disabilities; his blistering critique of a Glasgow 'regeneration project' that would have forced the displacement of 400 families, destroyed the Sighthill Stone Circle and removed memorial statues from George Square; and his support of an artist-led campaign to re-purpose the national arts funding body Creative Scotland.

${ }^{2}$ UKIP is the United Kingdom Independence Party, bogeyman of the British cosmopolitan left. Best known for populist campaigns against the EU and immigration, many UKIP politicians have been accused of racism. Mark Cousins elaborated on his response to the essay in the Sunday Herald of 23 December 2012.

${ }^{3}$ It should be noted that the SNP operate in a largely hostile media environment and frequently have any link to 'anti-Englishness' - including statements forcefully rebutting and attacking it - used against them. The day after the government statement 'disagreeing' with Gray, the Scottish Express asked 'since when did a "government" consider it necessary to issue a statement rejecting the not terribly shocking views of a slightly eccentric writer? It goes to show just how sensitive the Nationalists, whether in government or on the wilder fringes of social media, are about accusations of being in the remotest way anti-English' (Gill, 2012). Reasons to be 'sensitive' include the same article's blame of the SNP for what it had clearly condemned: 'The talk of colonists sounds like something spewed out by a rabid old Nationalist from the 1930s, but it is the kind of nonsense that Mr Salmond and his followers have encouraged'.
} 